Research Article

\title{
Transfer Mechanism of Lanthanum from Rare Earth Containing Iron Ore to Pig Iron during the Blast Furnace Process
}

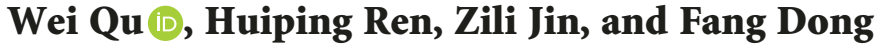 \\ Key Laboratory of Integrated Exploitation of Bayan Obo Multi-Metal Resources, Baotou 014010, China \\ Correspondence should be addressed to Wei Qu; qwandzls@126.com
}

Received 23 January 2019; Revised 13 April 2019; Accepted 8 May 2019; Published 26 May 2019

Academic Editor: Carlos Garcia-Mateo

Copyright (C 2019 Wei Qu et al. This is an open access article distributed under the Creative Commons Attribution License, which permits unrestricted use, distribution, and reproduction in any medium, provided the original work is properly cited.

\begin{abstract}
Some iron ores are enriched with lanthanum element, for example, the Bayan Obo iron ore in China. The pig iron which used the Bayan Obo iron ore as the raw material was obtained from the blast furnace of Baotou Steel in order to research the transfer mechanisms of lanthanum from rare earth containing iron ore to pig iron during the blast furnace process. The thermodynamic process was calculated using the molecular-ion coexistence model. The slag-metal reactions of the hearth were carried out in the tube furnace. The morphology and phase structure in the pig iron were observed by SEM and XRD. The rule of lanthanum transfer was analyzed by physical and chemical analyses using ICP-MS. Fourier-transform infrared spectroscopy was used for analyzing the vibrations of functional groups. The results indicate that the $\mathrm{La}_{2} \mathrm{O}_{3}$ in the slag was reduced to $\mathrm{LaC}_{2}$ by carbon and then the $\mathrm{LaC}_{2}$ dissolved into the molten iron to form $\mathrm{La}$. At last, coke which has the oxygen-containing functional groups $(\mathrm{C}-\mathrm{OH}, \mathrm{C}=\mathrm{O}$, and $\mathrm{C}-\mathrm{O}-\mathrm{C}$ ) has capacity to absorb lanthanum that is dissolved in the molten iron during the blast furnace iron-making process, and increasing the lanthanum content in the slag leads to higher lanthanum concentration in the porous graphite phase of the pig iron. The coke is graphitized during the process and could remain in the pig iron as porous graphite phase which acts as the carrier of lanthanum.
\end{abstract}

\section{Introduction}

Previous researches [1-7] have confirmed the roles of rareearth elements (REEs), lanthanum in particular, in improving the performance of steels. Garrison et al. [8] and Liu and co-workers [9] reported that proper addition of lanthanum not only reduced the segregation of sulphur and phosphorus along the grain boundaries but also purified the steel melts and modified the inclusions in the steels. As a result, the impact toughness of the AF1410 ultrahigh strength and low-carbon steels were significantly improved. In addition, improved pitting resistance of a 316L stainless steel due to the addition of lanthanum was also reported [10]. Xia and co-workers' results showed that cooperative addition of boron and lanthanum could even increase the surface wear resistance of mild steel [11]. However, because of the high chemical reactivity and high affinity of REEs, including lanthanum, to oxygen, it has been a long-term challenge to properly add REEs into the molten steels and to control the actual concentration of the REEs in the steel $[12,13]$.

Some iron ores in the world, for example, the Bayan Obo ore in China, are enriched with various REEs. REEs normally exist as bastnaesite and monazite [14], which convert into RE oxides at high temperature, in the Bayan Obo ore. According to the Ellingham diagram, RE oxides could not been reduced during the blast furnace process [15]. Hence, during iron making process in the blast furnace (BF), almost all the rare earth elements are absorbed by the slag and eventually are rejected from the pig iron which is used for subsequent steelmaking [16]. However, $\mathrm{Yu}$ and co-workers [17] reported that the REEs in the iron ore can be partially retained in the steel as residuals after the production process. The long-term standing questions are whether the REEs in the iron ores can be partially retained in the pig iron and consequently be inherited by steels. The present work started with analysis of the REEs in the pig iron that was produced using Bayan Obo iron ore at Baotou Steel, China. In order to clarify the 
mechanism, the iron-making process in the blast furnace hearth was simulated. The research outcomes may form a basis to develop new techniques for effective addition of REEs in steels and for recycling the REEs from the blast furnace slag.

\section{Experimental}

2.1. Samples. Pig iron produced at Baotou Iron \& Steel (Group) Co, China, using the Bayan Obo iron ore that was enriched with REEs was used. Its chemical composition is listed in Table $1.300 \mathrm{~g}$ of obtained pig iron was re-melted at $1723 \mathrm{~K}$ followed by quenching in iced brine to achieve solidification while avoiding graphite precipitation. This iron is termed as blast furnace pig iron. To further verify the lanthanum absorption capability of coke, reactions in the blast furnace hearth were simulated in the laboratory. The blast furnace pig iron as listed in Table 1 and the blast furnace slag produced at Baotou Steel were used. The composition of the original slag is listed in Table 2. Two Laenhanced slags were prepared through addition of additional $0.3 \mathrm{wt} \% \cdot \mathrm{La}_{2} \mathrm{O}_{3}$ and $0.9 \mathrm{wt} \% \cdot \mathrm{La}_{2} \mathrm{O}_{3}$ and coke that was also provided by Baotou Steel. The ingredient of the coke is listed in Table 3. In addition, to identify the rule of absorption by coke, the coke was oxidized by the Hummers method [18] with $5 \mathrm{~min}, 10 \mathrm{~min}$, and $20 \mathrm{~min}$, respectively. Pristine graphite (99.9\%) was purchased from Sinopharm Chemical Reagent Co., Ltd.

2.2. Thermodynamic Calculation of La Existential State in the Molten BF Slag. The lanthanum element existential states in the molten BF slag were characterized by the molecular-ion coexistence model which was put forward by Chuiko and corrected by Zhang $[19,20]$. Through the model, the chemical equilibrium relationships between ions, simple molecules, and composite molecules have been established, and the working concentration of each component was calculated according to the existing chemical equilibrium thermodynamic data to express the activity of each component. Referring to the phase diagrams of $\mathrm{CaO}, \mathrm{SiO}_{2}$, $\mathrm{Al}_{2} \mathrm{O}_{3}, \mathrm{MgO}, \mathrm{La}_{2} \mathrm{O}_{3}$, and $\mathrm{CaF}_{2}$, there were following structural units existing in the slag system:

(1) Simple ions: $\mathrm{Ca}^{2+}, \mathrm{Mg}^{2+}, \mathrm{La}^{3+}, \mathrm{O}^{2-}$, and $\mathrm{F}^{-}$

(2) Molecular compounds: $\mathrm{CaO}, \mathrm{SiO}_{2}, \mathrm{Al}_{2} \mathrm{O}_{3}, \mathrm{MgO}$, $\mathrm{La}_{2} \mathrm{O}_{3}, \mathrm{CaF}, 3 \mathrm{CaO} \cdot \mathrm{Al}_{2} \mathrm{O}_{3}, 12 \mathrm{CaO} \cdot 7 \mathrm{Al}_{2} \mathrm{O}_{3}, \mathrm{CaO} \cdot \mathrm{Al}_{2} \mathrm{O}_{3}$, $\mathrm{CaO} \cdot 2 \mathrm{Al}_{2} \mathrm{O}_{3}, \mathrm{CaO} \cdot 6 \mathrm{Al}_{2} \mathrm{O}_{3}, \mathrm{CaO} \cdot \mathrm{SiO}_{2}, \quad 3 \mathrm{CaO} \cdot 2 \mathrm{SiO}$, $3 \mathrm{CaO} \cdot 2 \mathrm{SiO}_{2}, 2 \mathrm{CaO} \cdot \mathrm{SiO}_{2}, 3 \mathrm{CaO} \cdot \mathrm{SiO}_{2}, 3 \mathrm{Al}_{2} \mathrm{O}_{3} \cdot 2 \mathrm{SiO}$, $2 \mathrm{MgO} \cdot \mathrm{SiO}_{2}, \mathrm{MgO} \cdot \mathrm{SiO}_{2}, \mathrm{MgO} \cdot \mathrm{Al}_{2} \mathrm{O}_{3}, \mathrm{Al}_{2} \mathrm{O}_{3} \cdot \mathrm{La}_{2} \mathrm{O}_{3}$, $11 \mathrm{Al}_{2} \mathrm{O}_{3} \cdot \mathrm{La}_{2} \mathrm{O}_{3}, 7 \mathrm{Al}_{2} \mathrm{O}_{3} \cdot 33 \mathrm{La}_{2} \mathrm{O}_{3}, 2 \mathrm{CaO} \cdot \mathrm{Al}_{2} \mathrm{O}_{3} \cdot \mathrm{SiO}_{2}$, $\mathrm{CaO} \cdot \mathrm{Al}_{2} \mathrm{O}_{3} \cdot 2 \mathrm{SiO}_{2}, \quad 2 \mathrm{CaO} \cdot \mathrm{MgO} \cdot 2 \mathrm{SiO}_{2}, \quad 3 \mathrm{CaO} \cdot \mathrm{MgO} \cdot$ $2 \mathrm{SiO}_{2}, \quad \mathrm{CaO} \cdot \mathrm{MgO} \cdot 2 \mathrm{SiO}_{2}, \quad 2 \mathrm{CaO} \cdot \mathrm{Al}_{2} \mathrm{O}_{3} \cdot \mathrm{CaF}_{2}$, and $11 \mathrm{CaO} \cdot 7 \mathrm{Al}_{2} \mathrm{O}_{3} \cdot \mathrm{CaF}_{2}$

Then, the equilibrium constant equations of the reaction of the structural units of the slag are established. At last, the activity of each component of slag has been calculated according to the equation of mass conservation:
TABle 1: Composition of the pig iron (wt.\%).

\begin{tabular}{lcccccc}
\hline Sample & C & Si & Mn & P & S & Fe \\
\hline Pig iron & 4.3 & 0.33 & 0.37 & 0.143 & 0.018 & 94.839 \\
\hline
\end{tabular}

TABle 2: Composition of the slag (wt.\%).

\begin{tabular}{lcccccc}
\hline No. & $\mathrm{CaO}$ & $\mathrm{SiO}_{2}$ & $\mathrm{MgO}$ & $\mathrm{Al}_{2} \mathrm{O}_{3}$ & $\mathrm{CaF}_{2}$ & $\mathrm{La}_{2} \mathrm{O}_{3}$ \\
\hline Original slag & 41.18 & 35.48 & 8.64 & 14.04 & 0.56 & 0.1 \\
La-enhanced slag 1 & 41.06 & 35.37 & 8.61 & 14.00 & 0.56 & 0.4 \\
La-enhanced slag 2 & 40.81 & 35.16 & 8.56 & 13.91 & 0.56 & 1 \\
\hline
\end{tabular}

Let $m_{1}=n_{\mathrm{CaO}}, \quad m_{2}=n_{\mathrm{SiO}_{2}}, \quad m_{3}=n_{\mathrm{Al}_{2} \mathrm{O}_{3}}, \quad m_{4}=n_{\mathrm{MgO}}$, $m_{5}=n_{\mathrm{CaF}_{2}}, \quad m_{6}=n_{\mathrm{La}_{2} \mathrm{O}_{3}}, \quad N_{1}=N_{\mathrm{CaO}}, \quad N_{2}=N_{\mathrm{SiO}_{2}}, \quad N_{3}=$ $N_{\mathrm{Al}_{2} \mathrm{O}_{3}}, \quad N_{4}=N_{\mathrm{MgO}}, \quad N_{5}=N_{\mathrm{CaF}_{2}}, \quad N_{6}=N_{\mathrm{La}_{2} \mathrm{O}_{3}}, \quad N_{7}=$ $N_{3 \mathrm{CaO} \cdot \mathrm{Al}_{2} \mathrm{O}_{3}}, N_{8}=N_{12 \mathrm{CaO} \cdot 7 \mathrm{Al}_{2} \mathrm{O}_{3}}, N_{9}=N_{\mathrm{CaO} \cdot \mathrm{Al}_{2} \mathrm{O}_{3}}, \ldots, N_{29}=$ $N_{2 \mathrm{CaO} \cdot \mathrm{Al}_{2} \mathrm{O}_{3} \cdot \mathrm{CaF}_{2}}$, and $N_{30}=N_{11 \mathrm{CaO} \cdot 7 \mathrm{Al}_{2} \mathrm{O}_{3} \cdot \mathrm{CaF}_{2}}$.

Hypothesized $\sum N$ is the total amount of substance in each structural unit when the slag is balanced. The $m_{1}, m_{2}$, $m_{3}, m_{4}, m_{5}$, and $m_{6}$ are the amounts of substance of $\mathrm{CaO}$, $\mathrm{SiO}_{2}, \mathrm{Al}_{2} \mathrm{O}_{3}, \mathrm{MgO}, \mathrm{CaF}_{2}$, and $\mathrm{La}_{2} \mathrm{O}_{3}$ before the reactions, respectively. $N_{i}(i=1,2,3, \ldots, 30)$ is the concentration of each component in the slag at equilibrium, defined as activity. Table 4 lists the chemical reaction equations which were involved in the model:

$$
\begin{aligned}
\sum_{i=1}^{30} N_{i}= & 1 \\
m_{1}= & \sum\left(\frac{1}{2} N_{1}+3 N_{7}+12 N_{8}+N_{9}+N_{10}+N_{11}+N_{12}\right. \\
& +3 N_{13}+2 N_{14}+3 N_{15}+2 N_{23}+N_{24}+2 N_{25} \\
& \left.+3 N_{26}+N_{27}+N_{28}+3 N_{29}+N_{30}\right) \\
m_{2}= & \sum\left(\frac{1}{2} N_{2}+N_{12}+2 N_{13}+N_{14}+N_{15}+2 N_{16}+N_{17}\right. \\
& +N_{18}+2 N_{14}+N_{23}+2 N_{24}+2 N_{25}+2 N_{26} \\
& \left.+N_{27}+2 N_{28}\right) \\
& \left.+N_{27}+N_{28}\right) \\
m_{5}= & \sum\left(\frac{1}{3} N_{5}+N_{29}+N_{30}\right) \\
m_{3}= & \left(N_{3}+N_{7}+7 N_{8}+N_{9}+2 N_{10}+6 N_{11}\right. \\
& \left.+3 N_{16}+N_{19}+N_{20}+11 N_{21}+7 N_{22}+N_{23}+7 N_{30}\right) \\
m_{4}= & \sum\left(\frac{1}{2} N_{4}+2 N_{17}+N_{18}+N_{19}+N_{25}+N_{26}\right. \\
& +4) \\
& +3) \\
&
\end{aligned}
$$


TABle 3: Composition of the coke (wt.\%).

\begin{tabular}{lccccccrr}
\hline Fixed carbon & \multicolumn{3}{c}{ Ash (12.64) } & & Volatile & Moisture & Sulphur \\
& $\mathrm{CaO}$ & $\mathrm{MgO}$ & $\mathrm{SiO}_{2}$ & $\mathrm{Al}_{2} \mathrm{O}_{3}$ & $\mathrm{P}_{2} \mathrm{O}_{5}$ & & 0.2 \\
\hline 85.32 & 4.20 & 1.35 & 55.0 & 24.50 & 3.21 & 1.06 & 0.78 \\
\hline
\end{tabular}

TABLE 4: The relevant expressions of chemical equations, Gibbs free energy, and mass action concentrations of complicated molecules in the molten slag [21-24].

\begin{tabular}{|c|c|c|}
\hline Chemical equations & $\Delta G(\mathrm{~J} / \mathrm{mol})$ & $N_{i}$ \\
\hline $3\left(\mathrm{Ca}^{2+}+\mathrm{O}^{2-}\right)+\left(\mathrm{Al}_{2} \mathrm{O}_{3}\right)=\left(3 \mathrm{CaO} \cdot \mathrm{Al}_{2} \mathrm{O}_{3}\right)$ & $-21771.36-29.3076 T$ & $N_{7}=\mathrm{K}_{1} \mathrm{~N}_{1}{ }^{3} \mathrm{~N}_{3}$ \\
\hline $12\left(\mathrm{Ca}^{2+}+\mathrm{O}^{2-}\right)+7\left(\mathrm{Al}_{2} \mathrm{O}_{3}\right)=\left(12 \mathrm{CaO} \cdot 7 \mathrm{Al}_{2} \mathrm{O}_{3}\right)$ & $-103240-311.1 T$ & $N_{8}=\mathrm{K}_{2} \mathrm{~N}_{1}{ }^{12} \mathrm{~N}_{3}{ }^{7}$ \\
\hline$\left(\mathrm{Ca}^{2+}+\mathrm{O}^{2-}\right)+\left(\mathrm{Al}_{2} \mathrm{O}_{3}\right)=\left(\mathrm{CaO} \cdot \mathrm{Al}_{2} \mathrm{O}_{3}\right)$ & $-23027.4-18.8406 T$ & $N_{9}=\mathrm{K} 3 \mathrm{~N}_{1} \mathrm{~N}_{3}$ \\
\hline$\left(\mathrm{Ca}^{2+}+\mathrm{O}^{2-}\right)+2\left(\mathrm{Al}_{2} \mathrm{O}_{3}\right)=\left(\mathrm{CaO} \cdot 2 \mathrm{Al}_{2} \mathrm{O}_{3}\right)$ & $-16747.2-25.54 T$ & $N_{10}=\mathrm{K}_{4} \mathrm{~N}_{1} \mathrm{~N}_{3}^{2}$ \\
\hline$\left(\mathrm{Ca}^{2+}+\mathrm{O}^{2-}\right)+6\left(\mathrm{Al}_{2} \mathrm{O}_{3}\right)=\left(\mathrm{CaO} \cdot 6 \mathrm{Al}_{2} \mathrm{O}_{3}\right)$ & $-22608.72-31.82 T$ & $N_{11}=\mathrm{K}_{5} \mathrm{~N}_{1} \mathrm{~N}_{3}{ }^{6}$ \\
\hline$\left(\mathrm{Ca}^{2+}+\mathrm{O}^{2-}\right)+\left(\mathrm{SiO}_{2}\right)=\left(\mathrm{CaO} \cdot \mathrm{SiO}_{2}\right)$ & $-81416-10.498 T$ & $N_{12}=\mathrm{K}_{6} \mathrm{~N}_{1} \mathrm{~N}_{2}$ \\
\hline $3\left(\mathrm{Ca}^{2+}+\mathrm{O}^{2-}\right)+2\left(\mathrm{SiO}_{2}\right)=\left(3 \mathrm{CaO} \cdot 2 \mathrm{SiO}_{2}\right)$ & $-236973+9.63 T$ & $N_{13}=\mathrm{K}_{7} \mathrm{~N}_{1}{ }^{3} \mathrm{~N}_{2}{ }^{2}$ \\
\hline $2\left(\mathrm{Ca}^{2+}+\mathrm{O}^{2-}\right)+\left(\mathrm{SiO}_{2}\right)=\left(2 \mathrm{CaO} \cdot \mathrm{SiO}_{2}\right)$ & $-160431+4.106 T$ & $N_{14}=\mathrm{K}_{8} \mathrm{~N}_{1}^{2} \mathrm{~N}_{2}$ \\
\hline $3\left(\mathrm{Ca}^{2+}+\mathrm{O}^{2-}\right)+\left(\mathrm{SiO}_{2}\right)=\left(3 \mathrm{CaO} \cdot \mathrm{SiO}_{2}\right)$ & $-93366-23.03 T$ & $N_{15}=\mathrm{K}_{9 \mathrm{~N}_{1}}{ }^{3} \mathrm{~N}_{2}$ \\
\hline $3\left(\mathrm{Al}_{2} \mathrm{O}_{3}\right)+2\left(\mathrm{SiO}_{2}\right)=\left(3 \mathrm{Al}_{2} \mathrm{O}_{3} \cdot 2 \mathrm{SiO}_{2}\right)$ & $-4354.27-10.467 T$ & $N_{16}=\mathrm{K}_{10 \mathrm{~N}_{3}}{ }^{3} \mathrm{~N}_{2}{ }^{2}$ \\
\hline $2\left(\mathrm{Mg}^{2+}+\mathrm{O}^{2-}\right)+\left(\mathrm{SiO}_{2}\right)=\left(2 \mathrm{MgO} \cdot \mathrm{SiO}_{2}\right)$ & $-86670+16.81 T$ & $N_{17}=\mathrm{K}_{11} \mathrm{~N}_{4}{ }^{2} \mathrm{~N}_{2}$ \\
\hline$\left(\mathrm{Mg}^{2+}+\mathrm{O}^{2-}\right)+\left(\mathrm{SiO}_{2}\right)=\left(\mathrm{MgO} \cdot \mathrm{SiO}_{2}\right)$ & $-30013-5.02 T$ & $N_{18}=\mathrm{K}_{12} \mathrm{~N}_{4} \mathrm{~N}_{2}$ \\
\hline$\left(\mathrm{Mg}^{2+}+\mathrm{O}^{2-}\right)+\left(\mathrm{Al}_{2} \mathrm{O}_{3}\right)=\left(\mathrm{MgO} \cdot \mathrm{Al}_{2} \mathrm{O}_{3}\right)$ & $-35530-2.09 T$ & $N_{19}=\mathrm{K} 13 \mathrm{~N}_{4} \mathrm{~N}_{3}$ \\
\hline$\left(\mathrm{Al}_{2} \mathrm{O}_{3}\right)+\left(2 \mathrm{La}^{2+}+3 \mathrm{O}^{2-}\right)=\left(\mathrm{Al}_{2} \mathrm{O}_{3} \cdot \mathrm{La}_{2} \mathrm{O}_{3}\right)$ & $-80799.277-16.49 T$ & $N_{20}=\mathrm{K} 14 \mathrm{~N}_{3} \mathrm{~N}_{6}^{2}$ \\
\hline $11\left(\mathrm{Al}_{2} \mathrm{O}_{3}\right)+\left(2 \mathrm{La}^{2+}+3 \mathrm{O}^{2-}\right)=\left(11 \mathrm{Al}_{2} \mathrm{O}_{3} \cdot \mathrm{La}_{2} \mathrm{O}_{3}\right)$ & $-11202.16-80.22 T$ & $N_{21}=\mathrm{K} 15 \mathrm{~N}_{3}{ }^{11} \mathrm{~N}_{6}$ \\
\hline $7\left(\mathrm{Al}_{2} \mathrm{O}_{3}\right)+33\left(2 \mathrm{La}^{2+} 3.3 \mathrm{O}^{2-}\right)=\left(7 \mathrm{Al}_{2} \mathrm{O}_{3} \cdot 33 \mathrm{La}_{2} \mathrm{O}_{3}\right)$ & $-383764.045-251.01 T$ & $N_{22}=\mathrm{K} 16 \mathrm{~N}_{3}^{7} \mathrm{~N}_{6}^{33}$ \\
\hline $2\left(\mathrm{Ca}^{2+}+\mathrm{O}^{2-}\right)+\left(\mathrm{Al}_{2} \mathrm{O}_{3}\right)+\left(\mathrm{SiO}_{2}\right)=\left(2 \mathrm{CaO} \cdot \mathrm{Al}_{2} \mathrm{O}_{3} \cdot \mathrm{SiO}_{2}\right)$ & $-61964.64-60.29 T$ & $N_{23}=\mathrm{K}_{1} 17 \mathrm{~N}_{1}^{2} \mathrm{~N}_{3} \mathrm{~N}_{2}$ \\
\hline$\left(\mathrm{Ca}^{2+}+\mathrm{O}^{2-}\right)+\left(\mathrm{Al}_{2} \mathrm{O}_{3}\right)+2\left(\mathrm{SiO}_{2}\right)=\left(\mathrm{CaO} \cdot \mathrm{Al}_{2} \mathrm{O}_{3} \cdot 2 \mathrm{SiO}_{2}\right)$ & $-13816.44-55.26 T$ & $N_{24}=\mathrm{K} 18 \mathrm{~N}_{1} \mathrm{~N}_{3} \mathrm{~N}_{2}^{2}$ \\
\hline $2\left(\mathrm{Ca}^{2+}+\mathrm{O}^{2-}\right)+\left(\mathrm{Mg}^{2+}+\mathrm{O}^{2-}\right)+2\left(\mathrm{SiO}_{2}\right)=\left(2 \mathrm{CaO} \cdot \mathrm{MgO} \cdot 2 \mathrm{SiO}_{2}\right)$ & $-73688-63.69 T$ & $N_{25}=\mathrm{K}_{1} 9 \mathrm{~N}_{1}{ }^{2} \mathrm{~N}_{4} \mathrm{~N}_{2}{ }^{2}$ \\
\hline $3\left(\mathrm{Ca}^{2+}+\mathrm{O}^{2-}\right)+\left(\mathrm{Mg}^{2+}+\mathrm{O}^{2-}\right)+2\left(\mathrm{SiO}_{2}\right)=\left(3 \mathrm{CaO} \cdot \mathrm{MgO} \cdot 2 \mathrm{SiO}_{2}\right)$ & $-315469+24.786 T$ & $N_{26}=\mathrm{K} 20 \mathrm{~N}_{1}^{3} \mathrm{~N}_{4} \mathrm{~N}_{2}^{2}$ \\
\hline$\left(\mathrm{Ca}^{2+}+\mathrm{O}^{2-}\right)+\left(\mathrm{Mg}^{2+}+\mathrm{O}^{2-}\right)+\left(\mathrm{SiO}_{2}\right)=\left(\mathrm{CaO} \cdot \mathrm{MgO} \cdot \mathrm{SiO}_{2}\right)$ & $-124766.6+3.376 T$ & $N_{27}=\mathrm{K} 21 \mathrm{~N}_{1} \mathrm{~N}_{4} \mathrm{~N}_{2}$ \\
\hline$\left(\mathrm{Ca}^{2+}+\mathrm{O}^{2-}\right)+\left(\mathrm{Mg}^{2+}+\mathrm{O}^{2-}\right)+2\left(\mathrm{SiO}_{2}\right)=\left(\mathrm{CaO} \cdot \mathrm{MgO} \cdot 2 \mathrm{SiO}_{2}\right)$ & $-80387-51.916 T$ & $N_{28}=\mathrm{K} 22 \mathrm{~N}_{1} \mathrm{~N}_{4} \mathrm{~N}_{2}^{2}$ \\
\hline $3\left(\mathrm{Ca}^{2+}+\mathrm{O}^{2-}\right)+3\left(\mathrm{Al}_{2} \mathrm{O}_{3}\right)+\left(\mathrm{Ca}^{2+}+2 \mathrm{~F}^{-}\right)=\left(3 \mathrm{CaO} \cdot 3 \mathrm{Al}_{2} \mathrm{O}_{3} \cdot \mathrm{CaF}_{2}\right)$ & $-44492-73.15 T$ & $N_{29}=\mathrm{K} 23 \mathrm{~N}_{1}^{3} \mathrm{~N}_{3} \mathrm{~N}_{5}$ \\
\hline $11\left(\mathrm{Ca}^{2+}+\mathrm{O}^{2-}\right)+7\left(\mathrm{Al}_{2} \mathrm{O}_{3}\right)+\left(\mathrm{Ca}^{2+}+2 \mathrm{~F}^{-}\right)=\left(11 \mathrm{CaO} \cdot 7 \mathrm{Al}_{2} \mathrm{O}_{3} \cdot \mathrm{CaF}_{2}\right)$ & $-228760-155.8 T$ & $N_{30}=\mathrm{K} 24 \mathrm{~N}_{1}{ }^{11} \mathrm{~N}_{3}{ }^{7} \mathrm{~N}_{5}$ \\
\hline
\end{tabular}

$$
m_{6}=\sum\left(\frac{1}{5} N_{6}+N_{20}+N_{21}+33 N_{22}\right)
$$

Simultaneous equations (1)-(7) and the Newton downhill method were used to iteratively calculate the above nonlinear equations using MatLab, and the activity of each structural unit can be acquired.

2.3. Simulation Treatment. For the abovementioned simulated experiments, one of the experimental groups: $33 \mathrm{~g}$ the three different slags, $100 \mathrm{~g}$ pig iron, and $6 \mathrm{~g}$ original coke, the other of the experimental groups: $33 \mathrm{~g}$ the original slag, $100 \mathrm{~g}$ pig iron, and $6 \mathrm{~g}$ coke which was oxidized different times ( $5 \mathrm{~min}, 10 \mathrm{~min}$, and $20 \mathrm{~min}$ ) were mixed and then melted at $1723 \mathrm{~K}$ in a corundum crucible using a tube furnace under the protection of purified argon atmosphere, as shown in Figure 1 . The heating rate to the holding temperature was $4 \mathrm{~K} / \mathrm{min}$. After isothermally holding at $1723 \mathrm{~K}$ for 30 minutes and mechanically stirring with a quartz tube, the melt was sucked into the quartz tube (inside diameter: $\Phi 10 \mathrm{~mm}$; outside diameter: $15 \mathrm{~mm}$ ) and then quenched into iced brine to solidify to the iron very fast to avoid graphite precipitation. This type of iron is termed as slag treated pig irons.
2.4. Extraction Treatment. One gram pig iron, including blast furnace pig iron and the slag-treated pig irons, was smashed into small pieces (the size was about $3 \mathrm{~mm}-5 \mathrm{~mm}$ ). Each pig iron was placed in $38 \%$ hydrochloric acid at $200^{\circ} \mathrm{C}$ on a hot plate. After the ferrite matrix was completely dissolved, the solution was filtered by a $0.2 \mu \mathrm{m}$ filter membrane to separate the insoluble substances for subsequent analysis. The purchased graphite also went through the extraction treatment as blank reference, which certified whether the graphite was oxidized during the above extraction process.

2.5. SEM and XRD Analysis of the Insoluble Substances. To identify the insoluble substances, X-ray diffraction was conducted on a PANalytical-X'Pert Powder diffractometer ( $\mathrm{Cu} \mathrm{K} \alpha$ radiation) operated at $40 \mathrm{kV}$ with scanning speed of $5 / \mathrm{min}$. The microstructural morphologies of the insoluble substances were examined in a Hitachi S-3400N scanning electron microscope (SEM).

2.6. Component Analysis of the Insoluble Substances. The insoluble substances were further dissolved by alkali fusion to turn the solid into solution for element analysis. The concentrations of lanthanum in both the ferrite and the insoluble substances were determined using a PerkinElmer 


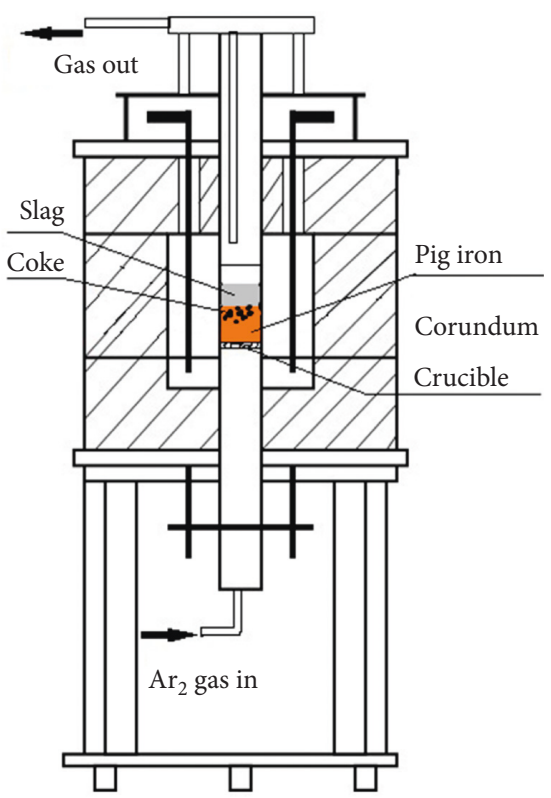

FIGURE 1: Schematic diagram of the slag-metal reaction in tube furnace.

NexIon-350X inductively coupled plasma mass spectrometry (ICP-MS) (data stabilization: RSD $<3 \%$ ).

2.7. Fourier-Transform Infrared Ray Analysis of the Insoluble Substances. Fourier-transform infrared (FT-IR) ray analysis was carried out on a Bruker Alpha FT-IR spectrometer. $2 \mathrm{mg}$ the insoluble substances which has been extracted from the pig irons was mechanically mixed with $200 \mathrm{mg}$ of $\mathrm{KBr}$ in an agate mortar. Then, the mixture was compressed into a disk at a pressure of $10 \mathrm{MPa}$ for $3 \mathrm{~min}$. The specimens were scanned from 500 to $4000 \mathrm{~cm}^{-1}$ to acquire the FT-IR spectrums.

\section{Results and Discussion}

3.1. Morphology and Structure Analysis of the Insoluble Substances. Figure 2(a) is a typical SEM micrograph of the pig iron after quenching in ice brine showing ferritic matrix (martensite) and the residual porous phase (pointed by the arrow). Figures 2(b) and 2(c) show SEM micrographs of the insoluble porous substances extracted from the blast furnace pig iron and the insoluble substances extracted from the slag treated pig iron, respectively. Figures 3(a) and 3(b) show their $\mathrm{X}$-ray diffraction (XRD) patterns. Indexing the XRD patterns indicated that both insoluble substances are graphite. There are no other crystalline phases observed. Because all the pig irons were re-melted followed by quenching in iced brine to solidify to iron very rapidly, neither cementite nor graphite could precipitate during this cooling process. The porous graphite as shown in Figure 2 should be directly from the pig iron melt as a remnant of the coke.

Because there was extra coke mixed with the pig iron and slag during the simulation treatments, the coke would be graphitized during the heating process [25]. A previous study [26] of the pig iron that was directly quenched from the melt in the blast furnace indicated that the coke tended to be distributed in the iron melt pool, which formed the coke bed. In addition, the pig iron and blast furnace slag of Baotou Steel are both tapping in the blast furnace trough at the same time. Coke is one of the main constituent parts of the tamping plug that Baotou Steel used. Thus, small portion of coke is unavoidable to be trapped in the pig iron when the blast furnace was tapping, due to flushing by the molten iron. Through comparison of Figure 2(b) with Figure 2(c), the porous graphite was derived from the coke, which remained solid in the molten iron. Lanthanum element existed in the porous graphitized coke of the pig iron which was the transferred carrier.

3.2. Lanthanum Concentrations in the Graphite and the Ferritic Matrix. Table 5 lists the lanthanum concentrations in the graphite, which was extracted from the blast furnace pig iron produced and from the slag-treated pig irons. For comparison, the lanthanum concentrations in the ferritic matrix are also listed. The lanthanum concentrations in the graphite, which were extracted from the pig irons, are approximately 600 to 4000 times higher than those in the ferritic matrix, in which the lanthanum concentrations are very close, varying from 0.11 to $0.21 \mathrm{ppm}$. In addition, slag treatment of the pig iron by the original slag did not increase the lanthanum concentration in the ferritic matrix in the graphite. However, the slag treatment of the pig irons by the La-enriched slag led to significant increase in lanthanum concentration in the graphite. This implies that the lanthanum element was absorbed and enriched in the graphite during the blast furnace process. Increasing the lanthanum content in the slag led to higher lanthanum concentration in the graphite of pig iron. Hence, it is reasonable to conclude that the graphite in the pig iron is a carrier of lanthanum.

\subsection{Mechanism of Lanthanum Enrichment in the Graphite.} The calculation results of the existence activities of the lanthanum element in the slag at $1723 \mathrm{~K}$ are shown in $\mathrm{Ta}-$ ble 6. Lanthanum element in the molten slag mainly exists in the form of $\left(\mathrm{La}_{2} \mathrm{O}_{3}\right)$. According to the Ellingham diagram, $\mathrm{La}_{2} \mathrm{O}_{3}$ could not be reduced to La by carbon [15]. However, the following reaction occurs:

$$
\begin{aligned}
\left(\mathrm{La}_{2} \mathrm{O}_{3}\right)+7 \mathrm{C}_{(\mathrm{s})} & =2 \mathrm{LaC}_{2(\mathrm{~s})}+3 \mathrm{CO}_{(\mathrm{g})}, \\
\Delta G^{\theta} & =1306287-827.25 T \\
\Delta G & =\Delta G^{\theta}+R T \ln \frac{p_{\mathrm{co}}^{3}}{a_{\left(\mathrm{La}_{2} \mathrm{O}_{3}\right)}} \\
& =1306287-827.25 T+R T \ln \frac{p_{\mathrm{co}}^{3}}{a_{\left(\mathrm{La}_{2} \mathrm{O}_{3}\right)}}
\end{aligned}
$$

where $R$ is the gas constant, $T$ is the temperature and $a_{\left(\mathrm{La}_{2} \mathrm{O}_{3}\right)}$ is the activity of $\left(\mathrm{La}_{2} \mathrm{O}_{3}\right)$. Hypothesizing that the partial pressure of $\mathrm{CO}, p_{\mathrm{co}}=1$, the $\left(\mathrm{La}_{2} \mathrm{O}_{3}\right)$ activities of the three groups of slag at $1723 \mathrm{~K}$ are substituted into equation (9) to obtain the respective Gibbs free energy changes, which are $-29305.6 \mathrm{~J}, \quad-49351.5 \mathrm{~J}$, and $-62440.2 \mathrm{~J}$, respectively. 


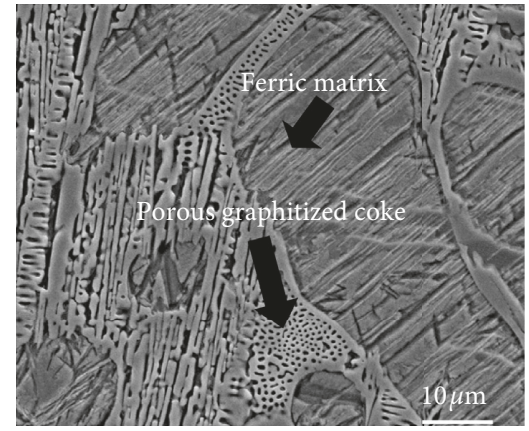

(a)

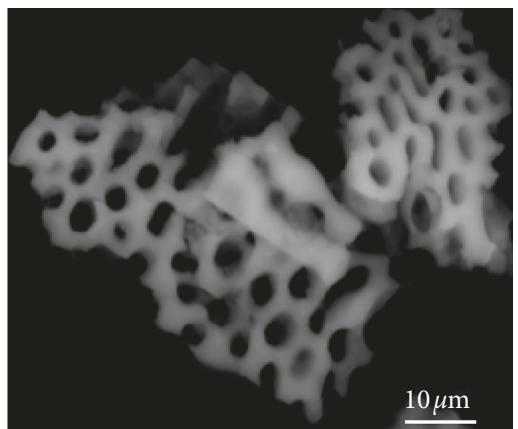

(b)

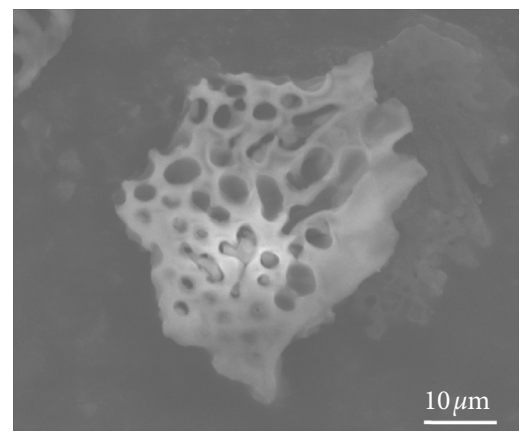

(c)

Figure 2: Morphologies of (a) the pig iron after quenching in ice brine, (b) insoluble substances in the blast furnace pig iron, and (c) insoluble substances in pig iron treated by blast furnace slag.

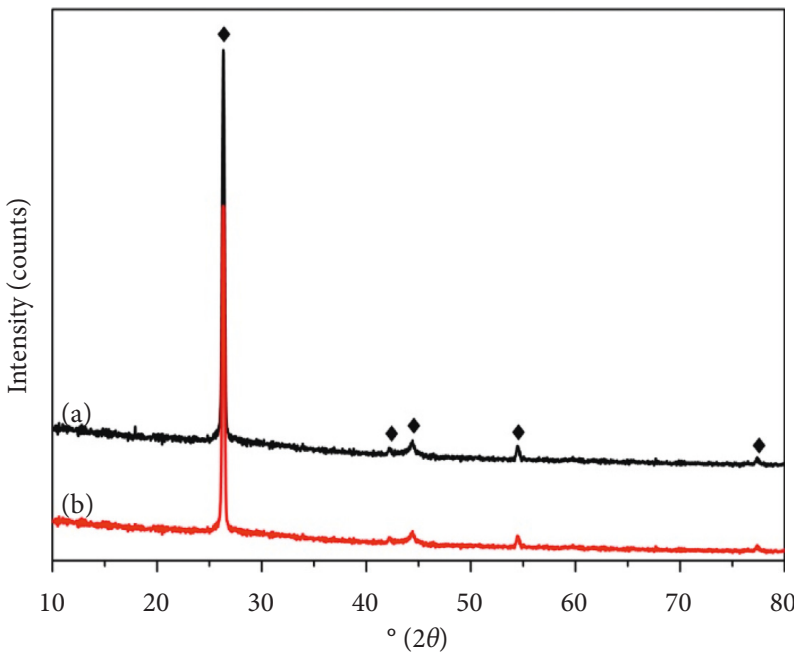

- Graphite

Figure 3: Structures of the insoluble substances (a) in the blast furnace pig iron and (b) in the slag treated pig iron.

TABLE 5: Lanthanum concentrations in the pig irons.

\begin{tabular}{lccc}
\hline & Samples & In graphite (ppm) & In ferritic matrix (ppm) \\
\hline Baotou steel pig iron & & 88.15 & 0.13 \\
\hline \multirow{3}{*}{ Pig irons treated by blast furnace slag } & Original slag & 86.76 & 0.11 \\
& La-enriched slag 1 & 376.63 & 0.19 \\
& La-enriched slag 2 & 933.54 & 0.21 \\
\hline
\end{tabular}

Therefore, $\mathrm{La}_{2} \mathrm{O}_{3}$ can be reduced to $\mathrm{LaC}_{2}$ by carbon at $1723 \mathrm{~K}$. Then, the $\mathrm{LaC}_{2}$ could be dissolved in the molten iron as shown in the following equation:

$$
\begin{aligned}
\mathrm{LaC}_{2(\mathrm{~s})} & =[\mathrm{La}]+2[\mathrm{C}], \\
\Delta G^{\theta} & =433190-256.99 T .
\end{aligned}
$$

The standard Gibbs free energy for the dissolution of carbon in molten iron is

$$
\begin{aligned}
\mathrm{C}_{(\mathrm{s})} & =[\mathrm{C}], \\
\Delta G^{\theta} & =22590-42.26 T .
\end{aligned}
$$

Combining equations (8), (10), and (11), the following can be obtained:

$$
\begin{aligned}
\left(\mathrm{La}_{2} \mathrm{O}_{3}\right)+3 \mathrm{C}_{(\mathrm{s})}= & 2[\mathrm{La}]+3 \mathrm{CO}_{(\mathrm{g})}, \\
\Delta G^{\theta}= & 2082307-1172.19 T, \\
\Delta G= & \Delta G^{\theta}+R T \ln \frac{p_{\mathrm{co}}^{3} a_{[\mathrm{La}]}^{2}}{a_{\left(\mathrm{La}_{2} \mathrm{O}_{3}\right)}} \\
= & 2082307-1172.19 T \\
& +R T \ln \frac{p_{\mathrm{co}}^{3} f_{[\mathrm{La}]}^{2}[\% \mathrm{La}]^{2}}{a_{\left(\mathrm{La}_{2} \mathrm{O}_{3}\right)}} .
\end{aligned}
$$

The process is that the rare earth lanthanum in the blast furnace slag is first reduced to $\mathrm{LaC}_{2}$ by carbon, and then 
TABle 6: Activities of each states of La element in the different La concentration slag [27].

\begin{tabular}{lcc}
\hline No. & Existential state of La & Activity \\
\hline & $\mathrm{La}_{2} \mathrm{O}_{3}$ & $1.90 \times 10^{-3}$ \\
1 & $\mathrm{Al}_{2} \mathrm{O}_{3} \cdot \mathrm{La}_{2} \mathrm{O}_{3}$ & $8.92 \times 10^{-7}$ \\
& $11 \mathrm{Al}_{2} \mathrm{O}_{3} \cdot \mathrm{La}_{2} \mathrm{O}_{3}$ & $8.80 \times 10^{-13}$ \\
& $7 \mathrm{Al}_{2} \mathrm{O}_{3} \cdot 33 \mathrm{La}_{2} \mathrm{O}_{3}$ & $1.43 \times 10^{-96}$ \\
\hline & $\mathrm{La}_{2} \mathrm{O}_{3}$ & $7.70 \times 10^{-3}$ \\
2 & $\mathrm{Al}_{2} \mathrm{O}_{3} \cdot \mathrm{La}_{2} \mathrm{O}_{3}$ & $3.54 \times 10^{-6}$ \\
& $11 \mathrm{Al}_{2} \mathrm{O}_{3} \cdot \mathrm{La}_{2} \mathrm{O}_{3}$ & $3.30 \times 10^{-12}$ \\
& $7 \mathrm{Al}_{2} \mathrm{O}_{3} \cdot 33 \mathrm{La}_{2} \mathrm{O}_{3}$ & $9.13 \times 10^{-77}$ \\
\hline & $\mathrm{La}_{2} \mathrm{O}_{3}$ & $1.92 \times 10^{-2}$ \\
& $\mathrm{Al}_{2} \mathrm{O}_{3} \cdot \mathrm{La}_{2} \mathrm{O}_{3}$ & $8.68 \times 10^{-6}$ \\
3 & $11 \mathrm{Al}_{2} \mathrm{O}_{3} \cdot \mathrm{La}_{2} \mathrm{O}_{3}$ & $7.14 \times 10^{-12}$ \\
& $7 \mathrm{Al}_{2} \mathrm{O}_{3} \cdot 33 \mathrm{La}_{2} \mathrm{O}_{3}$ & $9.16 \times 10^{-64}$ \\
\hline
\end{tabular}

$\mathrm{LaC}_{2}$ is dissolved into the molten iron to form [La]. If the equilibrium is reached at $1723 \mathrm{~K}, \Delta G=0$ :

$$
\ln \frac{f_{[\mathrm{La}]}^{2}[\% \mathrm{La}]^{2}}{a_{\left(\mathrm{La}_{2} \mathrm{O}_{3}\right)}}=\frac{-2082307+1172.19 \times 1723}{8.314 \times 1723}=-4.372 .
$$

Replace $e$ to the base 10 logarithmic form, we get

$$
\log \frac{f_{[\mathrm{La}]}^{2}[\% \mathrm{La}]^{2}}{a_{\left(\mathrm{La}_{2} \mathrm{O}_{3}\right)}}=\frac{-4.372}{\ln 10}=-1.899
$$

$2 \log f_{[\mathrm{La}]}+2 \log [\% \mathrm{La}]-\log a_{\left(\mathrm{La}_{2} \mathrm{O}_{3}\right)}+1.899=0$.

The interaction coefficients between carbon and lanthanum are as follows [23]:

$$
\begin{aligned}
e_{\mathrm{La}}^{\mathrm{C}}= & \frac{-341.4}{T}+0.158=\frac{-341.4}{1723} \\
& +0.158=-0.04 \\
e_{\mathrm{La}}^{\mathrm{La}}= & \frac{-29.4}{T}+0.0027=\frac{-29.4}{1723} \\
& +0.0027=-0.014, \\
\log f_{[\mathrm{La}]}= & e_{\mathrm{La}}^{\mathrm{C}}[\% \mathrm{C}]+e_{\mathrm{La}}^{\mathrm{La}}[\% \mathrm{La}]=-0.04[\% \mathrm{C}] \\
& -0.014[\% \mathrm{La}] .
\end{aligned}
$$

Combining equations (15) and (19) and substituting the $\mathrm{La}_{2} \mathrm{O}_{3}$ activities of the three groups of slag can be solved the [\% La] which were the concentrations of lanthanum in the molten iron through the reduction reactions when the equilibrium states were reached, respectively. When the $[\% \mathrm{C}]$ in the molten iron is $4.3 \%$, the equilibrium concentrations of lanthanum in the molten iron are $0.00728 \%, 0.01465 \%$, and $0.02314 \%$, respectively. The actual concentrations of lanthanum in the molten iron were far below the equilibrium concentrations. Therefore, $\mathrm{La}_{2} \mathrm{O}_{3}$ in the slag was reduced to $\mathrm{LaC}_{2}$ by carbon and then the $\mathrm{LaC}_{2}$ dissolved into the molten iron to form, $\mathrm{La}$.

To further verify the mechanism of lanthanum element enrichment in the graphitized coke, FT-IR analysis has been

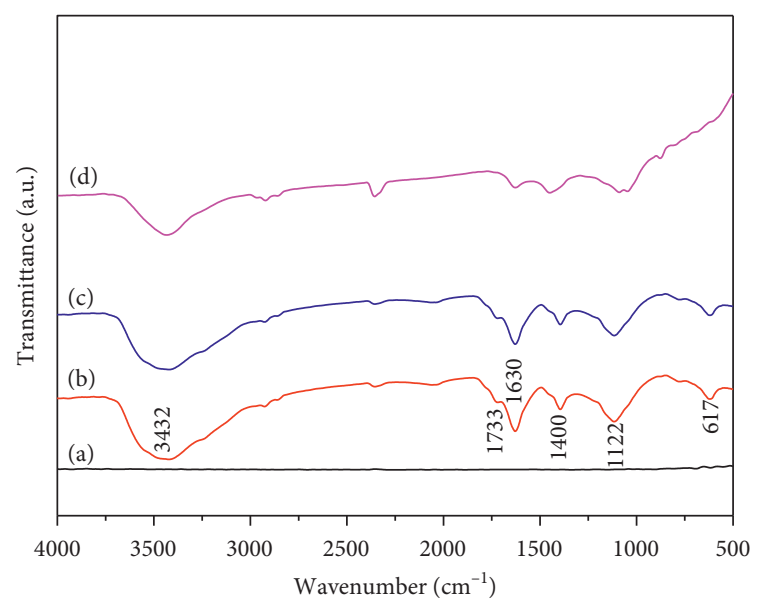

FIGURE 4: FT-IR spectra of (a) pristine graphite, (b) the porous graphite extracted from blast furnace pig iron, (c) the porous graphite extracted from the slag treated pig iron, and (d) the original coke.

TABle 7: Characteristics of peaks in Figure 4.

\begin{tabular}{lcc}
\hline $\begin{array}{l}\text { Peak position } \\
\left(\mathrm{cm}^{-1}\right)\end{array}$ & Cause of the peak & Reference \\
\hline 3432 & $\begin{array}{c}\text { O-H stretching vibration from } \\
\text { hydroxyl and water molecule }\end{array}$ & {$[31,32]$} \\
1733 & $\begin{array}{c}\text { C=O stretching vibration from } \\
\text { carbonyl and carboxylic groups } \\
\text { C=C stretching mode from } \\
\text { unoxidized graphitic domains }\end{array}$ & {$[33]$} \\
1630 & $\begin{array}{c}{[34]} \\
\text { Tertiary C-OH groups deformation } \\
\text { vibration }\end{array}$ & {$[35]$} \\
1122 & $\begin{array}{c}\text { C-O-C stretching vibration } \\
617\end{array}$ & $\begin{array}{c}\text { Stretching vibration } \mathrm{CO}_{2} \text { molecule } \\
\text { on surface of oxide graphite }\end{array}$ \\
\hline
\end{tabular}

conducted. Figure 4 shows the spectra of the pristine graphite (as blank reference) (a), the graphite directly extracted from the blast furnace pig iron (b), the graphite extracted from Laenriched slag treated pig iron (c), and original coke (d). The variations of the transmittance with the wavelength of the infrared ray are typical features of the oxygen-containing functional groups, just as the graphite oxide in the previous works [28-30], because the FT-IR spectrum shows constant transmittance of pristine graphite as the curve (a) shows, which indicated that there were not any oxygencontaining functional groups and the oxygen-containing functional groups do not form during the extraction process. However, the spectrums for the pig iron graphite (curves (b) and (c)) and the original coke (curve (d)) show variations of the transmittance, indicating vibration of oxygencontaining functional groups. More importantly, the three spectrums ((b), (c), and (d)) show the same shape. This verifies that the oxygen-containing functional groups of porous graphite in the pig irons originated from the original coke as the raw material for blast furnace iron-making.

The main vibration peaks of spectrums (b), (c), and (d) are summarized in Table 7. Comparing spectrums (b), (c), with (d), the broad peaks shifted from $3432 \mathrm{~cm}^{-1}$, which might be attributed to the complexation of metal ion with 


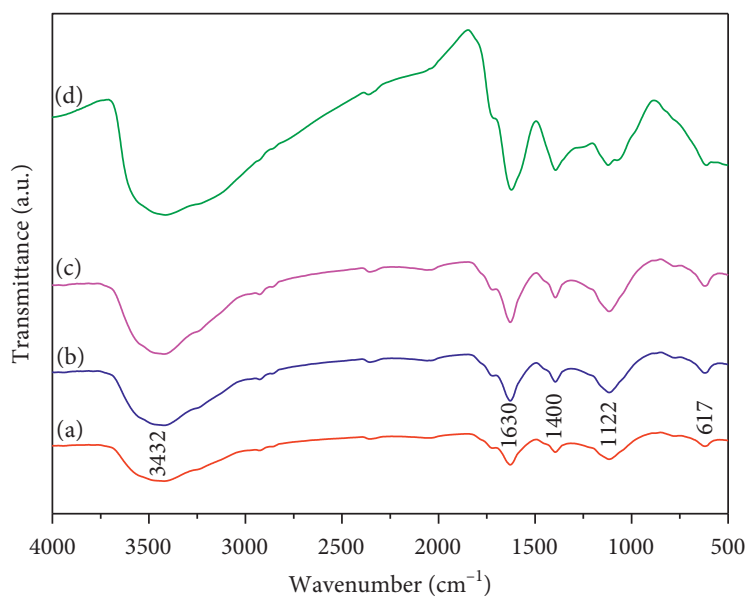

FiguRe 5: Fourier-transform infrared spectra: (a) original coke; (b) coke oxidation 5 min; (c) coke oxidation 10 min; (d) Ccke oxidation $20 \mathrm{~min}$.

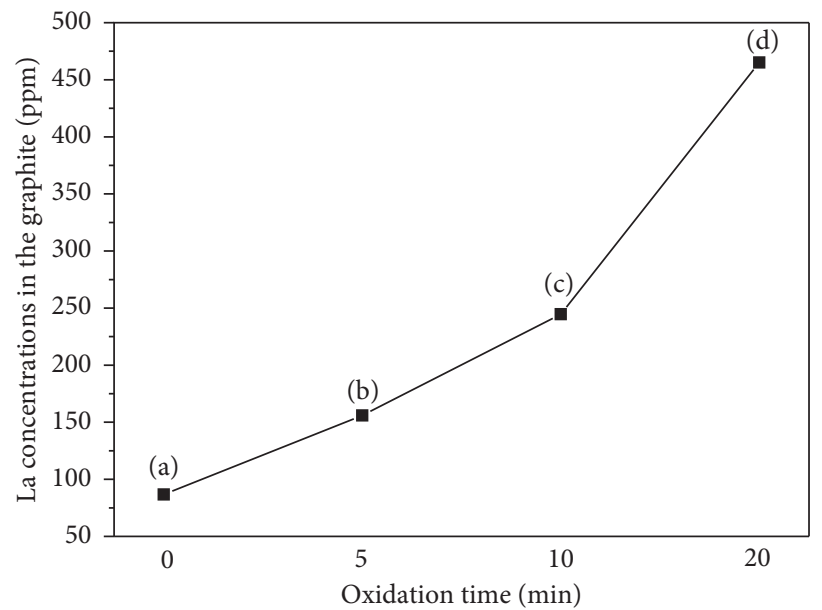

FIGURE 6: Content of lanthanum in porous graphite phase with different oxidation times after slag-iron reaction: (a) without oxidation; oxidation for (b) $5 \mathrm{~min}$; (c) $10 \mathrm{~min}$; and (d) $20 \mathrm{~min}$.
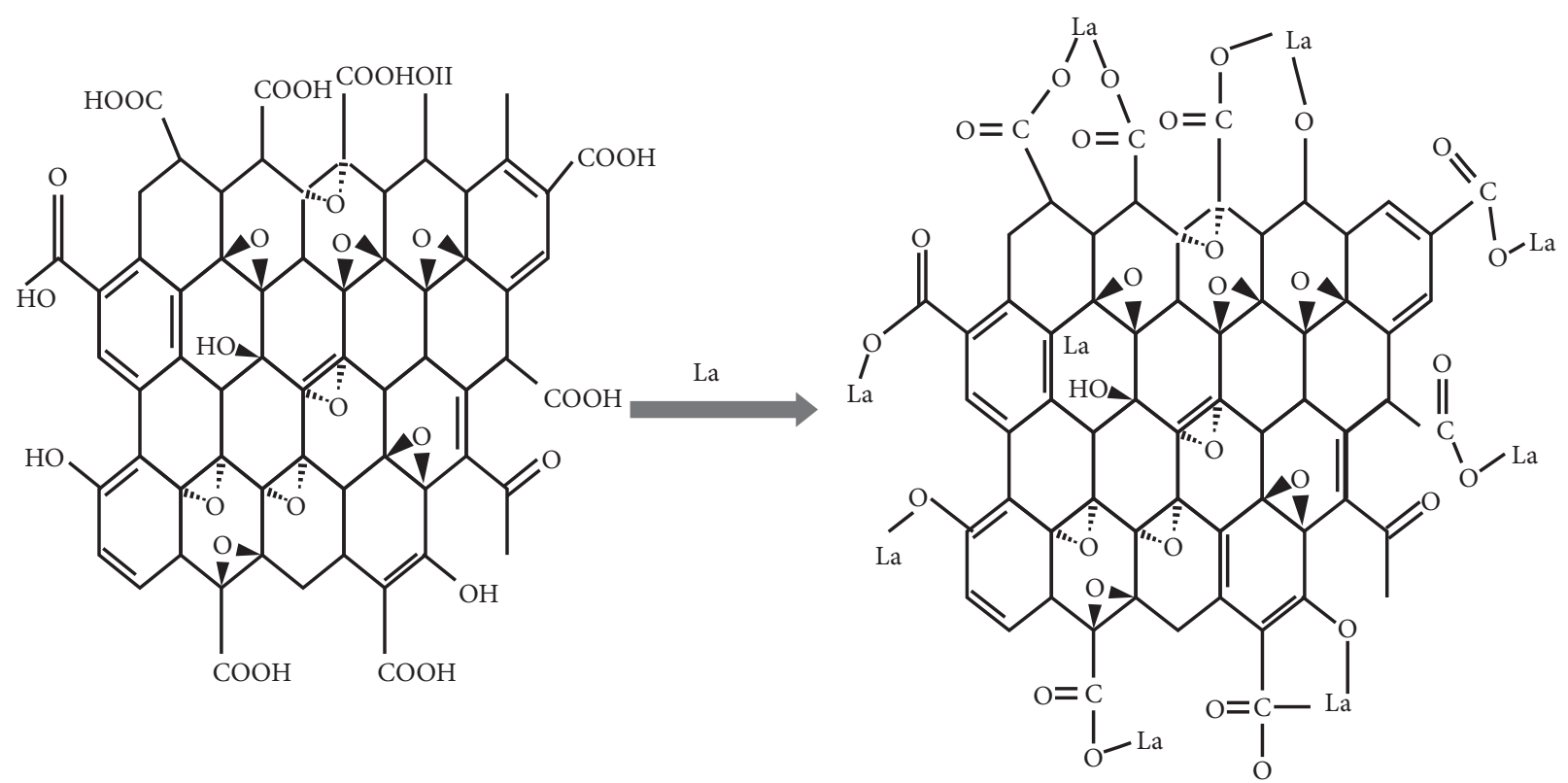

FIgURE 7: Schematic diagram of the mechanism for the adsorption of lanthanum on the structure of carbocycle. 
the ionized -OH group of "free" hydroxyl groups and bonded -OH bands of carboxylic acids. The peaks at $1733 \mathrm{~cm}^{-1}$ considerably might be due to the complexation between metal ion and $-\mathrm{C}=\mathrm{O}$ groups in carboxylic acid and carbonyl moieties of graphite oxide [37]. The peaks at $1400 \mathrm{~cm}^{-1}$ are ascribed to the $-\mathrm{OH}$ in-plane bending vibration combined with the metal ion $[38,39]$. The variation in peaks at $1122 \mathrm{~cm}^{-1}$ could represent $\mathrm{C}-\mathrm{O}-\mathrm{C}$ stretching vibration due to the metal ion enter between the elementary graphene layers [36]. Therefore, $\mathrm{C}=\mathrm{C}$ of the graphitic carbocycle will be stretching which is reflected by the variation in peaks at $1630 \mathrm{~cm}^{-1}$ [34].

Figure 5 shows the coke which was oxidized by the Hummers method with different times. The amplitudes of the main vibration peaks of spectrums were high with the extension of oxidation time which indicated the increase of oxygen-containing functional groups. After the adsorption reaction between the molten iron and slag, the content of lanthanum in the graphite increases with the increase of the oxygen-containing functional groups, as Figure 6 shows. Therefore, the key to the absorption reaction is the oxygencontaining functional groups adsorption mechanism.

During iron-making process, the molten iron, slag, and coke are mixed in the blast furnace hearth and blast furnace trough. Firstly, $\mathrm{La}_{2} \mathrm{O}_{3}$ in the slag was reduced to $\mathrm{LaC}_{2}$ by carbon and then the $\mathrm{LaC}_{2}$ dissolved into the molten iron to form La. At last, the coke, which has oxygen-containing groups, is responsible for the La absorption from the molten iron. The results indicated that the coke as the raw material for blast furnace iron-making contains oxygen-containing functional groups $(\mathrm{C}-\mathrm{OH}, \mathrm{C}=\mathrm{O}$, and $\mathrm{C}-\mathrm{O}-\mathrm{C})$, which are the carriers of the lanthanum element as shown in Figure 7.

\section{Conclusions}

(1) The SEM observation and XRD analysis results indicate that the microstructures of the pig iron cooled with iced brine are ferritic matrix and the porous graphite phase which is derived from the extra graphitized coke

(2) The concentration of the lanthanum in the porous graphite of the pig iron increases with the concentration of the lanthanum in the molten slag and amount of the oxygen-containing functional groups by the ICP-MS detection

(3) Coke has the capability to absorb lanthanum from the molten iron by the $\mathrm{C}-\mathrm{OH}, \mathrm{C}=\mathrm{O}$, and $\mathrm{C}-\mathrm{O}-\mathrm{C}$ oxygen-containing functional groups.

In a word, the porous graphite in the pig iron acts as the carrier to transfer the lanthanum from iron ore to pig iron.

\section{Data Availability}

The data used to support the findings of this study are included within the article.

\section{Conflicts of Interest}

The authors declare that they have no conflicts of interest.

\section{Acknowledgments}

The authors acknowledge the Natural Science Foundation of China (Grant no. 51261018) for funding support and Baotou Iron \& Steel (Group) Co., Ltd. for providing the relevant samples.

\section{References}

[1] Q. Q. Ma, C. C. Wu, G. G. Cheng, and F. W. Li, "Characteristic and formation mechanism of inclusions in 2205 duplex stainless steel containing rare earth elements," Materials Today: Proceedings, vol. 2, no. 2, pp. 300-305, 2015.

[2] X. a. Wang, M. Yan, R. Liu, and Y. Zhang, "Effect of rare earth addition on microstructure and corrosion behavior of plasma nitrocarburized M50NiL steel," Journal of Rare Earths, vol. 34, no. 11, pp. 1148-1155, 2016.

[3] S. Song, Y. Xu, X. Chen, and X. Jiang, "Effect of rare earth cerium and impurity tin on the hot ductility of a Cr-Mo low alloy steel," Journal of Rare Earths, vol. 34, no. 10, pp. 1062-1068, 2016.

[4] M. Huang, Y. Wang, C.-H. Chu, M.-X. Zhang, H.-B. Wang, and S.-X. Xue, "Wear resistance of alumina-coated oil casing steel N80 via MAO with rare earth additive," Ceramics International, vol. 43, no. 8, pp. 6397-6402, 2017.

[5] Y. Zhu, J. Zhuang, Y. Yu, and X. Zeng, "Research on anticorrosion property of rare earth inhibitor for X70 steel," Journal of Rare Earths, vol. 31, no. 7, pp. 734-740, 2013.

[6] L. M. Wang, Q. Lin, L. J. Yue, L. Liu, F. Guo, and F. M. Wang, "Study of application of rare earth elements in advanced low alloy steels," Journal of Alloys and Compounds, vol. 451, no. 12, pp. 534-537, 2008.

[7] S. K. Samanta, S. K. Mitra, and T. K. Pal, "Effect of rare earth elements on microstructure and oxidation behavior in TIG weldments of AISI 316L stainless steel," Materials Science and Engineering: A, vol. 430, no. 1-2, pp. 242-247, 2006.

[8] W. M. Garrison Jr. and J. L. Maloney, "Effect of sintering atmosphere and carbon content on the densification and microstructure of laser-sintered M2 high-speed steel powder," Materials Science and Engineering: A, vol. 403, no. 1-2, pp. 299-310, 2005.

[9] H.-L. Liu, C.-J. Liu, and M.-F. Jiang, "Effect of rare earths on impact toughness of a low-carbon steel," Materials \& Design, vol. 33, pp. 306-312, 2012.

[10] H. J. Yang, K. Yang, and B. C. Zhang, "Pitting corrosion resistance of La added 316L stainless steel in simulated body fluids," Materials Letters, vol. 61, no. 4-5, pp. 1154-1157, 2007.

[11] Y. Q. Xia, W. M. Liu, L. G. Yu, N. Han, and Q. J. Xue, "Investigation on the tribological properties of boron and lanthanum permeated mild steel," Materials Science and Engineering: A, vol. 354, no. 1-2, pp. 17-23, 2003.

[12] P. E. Waudby, "Rare earth additions to steel," International Materials Reviews, vol. 23, no. 1, pp. 74-98, 1978.

[13] C. L. Li, "Some suggestions on application of rare earth in steel," Chinese Rare Earths, vol. 22, no. 4, pp. 1-6, 2001.

[14] J. Ren, S. Song, A. Lopez-Valdivieso, and S. Lu, "Selective flotation of bastnaesite from monazite in rare earth concentrates using potassium alum as depressant," International Journal of Mineral Processing, vol. 59, no. 3, pp. 237-245, 2000.

[15] H. J. T. Ellingham, "Reductibility of oxides and sulphides in metallurgical processes," J. Soc. Chem. Ind.vol. 63, no. 5, pp. 125-160, 1944. 
[16] K. Binnemans, P. T. Jones, B. Blanpain, T. Van Gerven, and Y. Pontikes, "Towards zero-waste valorisation of rare-earthcontaining industrial process residues: a critical review," Journal of Cleaner Production, vol. 99, pp. 17-38, 2015.

[17] Z. S. Yu, S. Q. Li, J. Wu et al., "Residual trace elements brought by iron ores in steels made in China," Iron and Steel Research Institute, vol. 33, no. 10, pp. 54-58, 1998.

[18] W. S. Hummers Jr. and R. E. Offeman, "Preparation of graphitic oxide," Journal of the American Chemical Society, vol. 80, no. 6, p. 1339, 1958.

[19] N. M. Chuiko, "On the structural theory of metallurgical slags," Ferrous Metals Journal, vol. 5, pp. 3-10, 1959.

[20] J. Zhang, "Application of the coexistence theory of slag structure to multicomponent slag systems," in Proceedings of the 4th International Conference on Molten Slags and Fluxes, pp. 244-249, Sendai, Japan, January 1992.

[21] R. H. Rein and J. Chipman, "Activities in the liquid solution $\mathrm{SiO}_{2}-\mathrm{CaO}-\mathrm{MgO}-\mathrm{Al}_{2} \mathrm{O}_{3}$ at $1600^{\circ} \mathrm{C}$," Transactions of the Metallurgical Society of the American Institute of Mining, Metallurgical and Petroleum Engineers, vol. 233, no. 2, pp. 415-425, 1965.

[22] H. Gaye and J. Welfringer, "Modelling of the thermodynamic properties of complex metallurgical slags," in Proceedings of the 2nd International Symposium on Metallurgical Slags and Fluxes, pp. 357-375, Lake Tahoe, NV, USA, November 1984.

[23] J. Zhang, "Coexistence theory of slag structure and its application to calculation of oxidizing capability of slag melts," Journal of Iron and Steel Research International, vol. 10, no. 1, pp. 1-9, 2003.

[24] B. P. Richards, "Relationships between interlayer spacing, stacking order and crystallinity in carbon materials," Journal of Applied Crystallography, vol. 1, no. 1, pp. 35-48, 1968.

[25] J. G. Peacey, W. G. Davenport, and W. K. Lu, The Iron Blast Furnace Theory and Practice, Pergamon Press Ltd., Hamilton, Canada, 1979.

[26] T. Du, Q. Y. Han, and C. Z. Wang, Application of Physical Chemistry of Rare Earth and Alkaline Earth in Materials, Science and Technology Press, Beijing, China, 1995.

[27] P. Wu and A. D. Pelton, "Coupled thermodynamic-phase diagram assessment of the rare earth oxide-aluminium oxide binary systems," Journal of Alloys and Compounds, vol. 179, no. 1-2, pp. 259-287, 1992.

[28] Y. Matsuo, K. Watanabe, T. Fukutsuka, and Y. Sugie, "Characterization of n-hexadecylalkylamine-intercalated graphite oxides as sorbents," Carbon, vol. 41, no. 8, pp. 1545-1550, 2003.

[29] F. B. Bujans, S. Cerveny, R. Verdejo et al., "Permanent adsorption of organic solvents in graphite oxide and its effect on the thermal exfoliation," Carbon, vol. 48, no. 4, pp. 1079-1087, 2010.

[30] G. V. Prudnikova, A. G. Vjatkin, A. V. Ermakov, A. M. Shikin, and V. K. Adamchuk, "Surface intercalation of graphite by lanthanum," Journal of Electron Spectroscopy and Related Phenomena, vol. 68, pp. 427-430, 1994.

[31] J. Shen, T. Li, Y. Long, M. Shi, N. Li, and M. Ye, "One-step solid state preparation of reduced graphene oxide," Carbon, vol. 50, no. 6, pp. 2134-2140, 2012.

[32] V. K. Gupta, T. A. Saleh, D. Pathania, B. S. Rathore, and G. Sharma, "A cellulose acetate based nanocomposite for photocatalytic degradation of methylene blue dye under solar light," Ionics, vol. 21, no. 6, pp. 1787-1793, 2015.

[33] T. A. Saleh, A. A. Al-Saadi, and V. K. Gupta, "Carbonaceous adsorbent prepared from waste tires: experimental and computational evaluations of organic dye methyl orange," Journal of Molecular Liquids, vol. 191, pp. 85-91, 2014.

[34] W. Chen, L. Yan, and P. R. Bangal, "Preparation of graphene by the rapid and mild thermal reduction of graphene oxide induced by microwaves," Carbon, vol. 48, no. 4, pp. 1146$1152,2010$.

[35] C. Nethravathi and M. Rajamathi, "Chemically modified graphene sheets produced by the solvothermal reduction of colloidal dispersions of graphite oxide," Carbon, vol. 46, no. 14, pp. 1994-1998, 2008.

[36] T. Szabó, O. Berkesi, P. Forgó et al., "Evolution of surface functional groups in a series of progressively oxidized graphite oxides," Chemistry of Materials, vol. 18, no. 11, pp. 2740-2749, 2006.

[37] P. Y. Shih, J. Y. Ding, and S. Y. Lee, "MAS-NMR and FTIR analyses on the structure of $\mathrm{CuO}$-containing sodium polyand meta-phosphate glasses," Materials Chemistry and Physics, vol. 80, no. 2, pp. 391-396, 2003.

[38] Y. M. Ren, N. Yan, J. Feng et al., "Adsorption mechanism of copper and lead ions onto graphene nanosheet $/ \delta-\mathrm{MnO}_{2}$," Materials Chemistry and Physics, vol. 136, no. 2-3, pp. 538544, 2012

[39] R. Han, Z. Lu, W. Zou, W. Daotong, J. Shi, and Y. Jiujun, "Removal of copper(II) and lead(II) from aqueous solution by manganese oxide coated sand," Journal of Hazardous Materials, vol. 137, no. 1, pp. 480-488, 2006. 


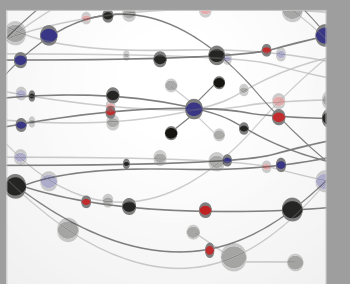

The Scientific World Journal
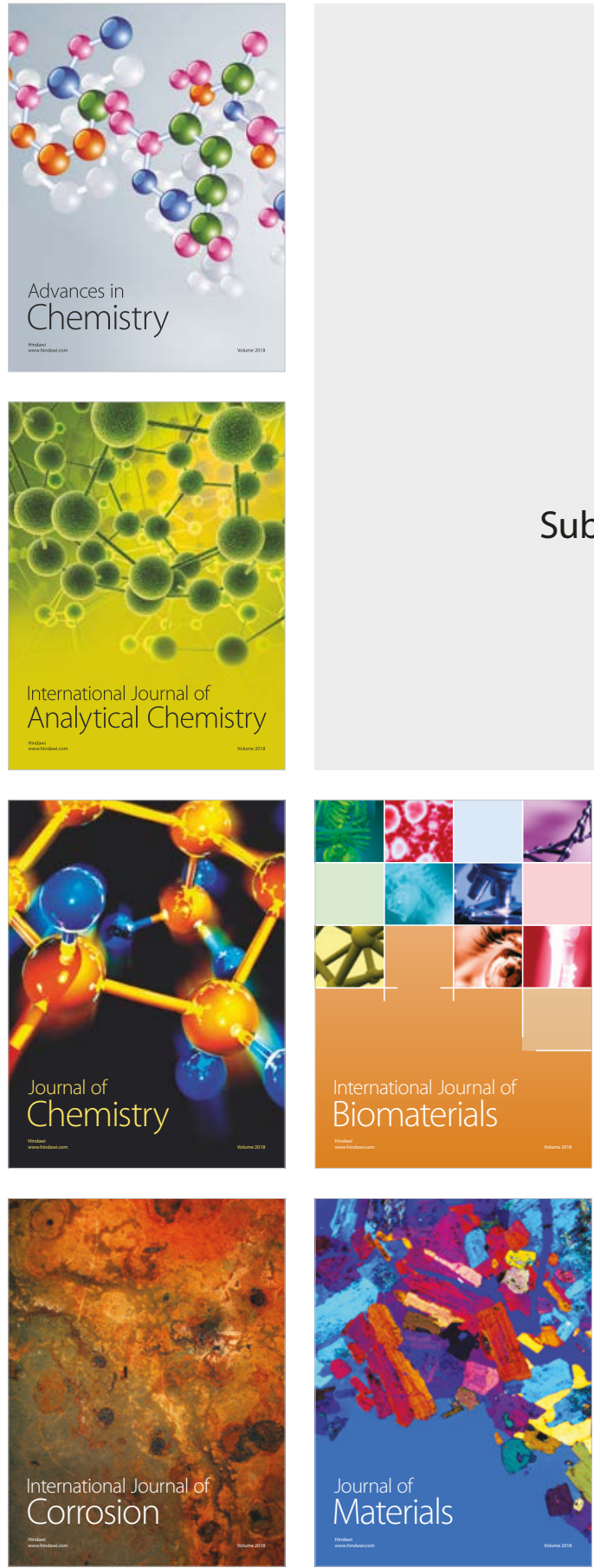

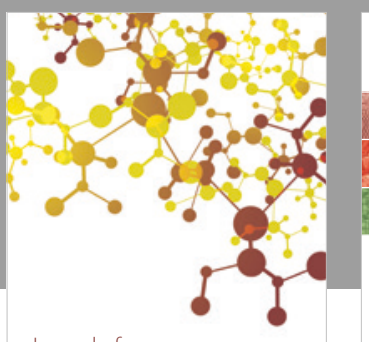

Journal of

Applied Chemistry
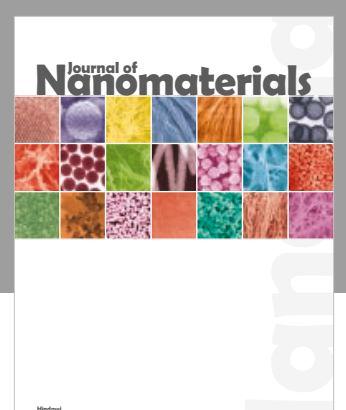

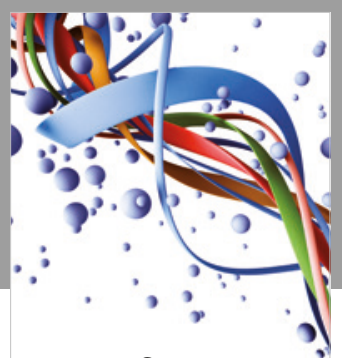

Scientifica

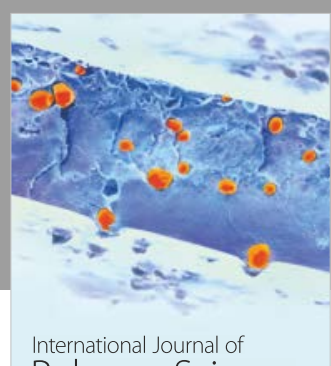

Polymer Science

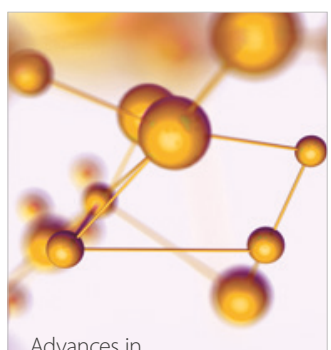

Physical Chemistry
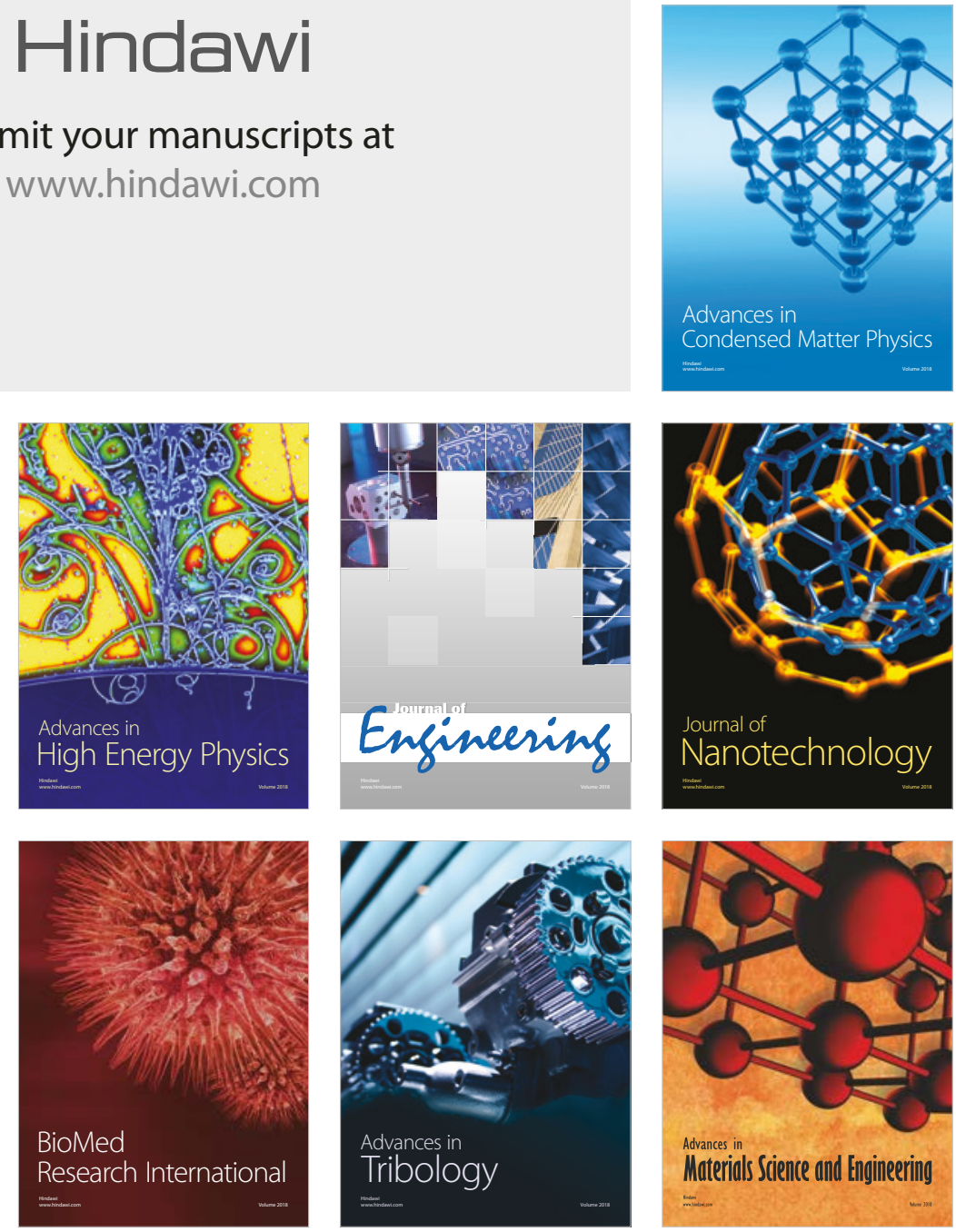